\title{
BOHUMIL JIROUŠEK
}

Uniwersytet Południowoczeski w Czeskich Budziejowicach, Czechy

\section{Proměny interpretace vzniku Československa v českém marxisticko-leninském myšlení}

Pro české, resp. československé, dějiny představuje rok 1918 zásadní mezník, který sice z hlediska kulturních potřeb národa není nikterak přelomový, z hlediska politického vývoje národa je však chápán jako zásadní, vedoucí k české národní samostatnosti ${ }^{1}$. Již $\mathrm{v}$ tom je ukryt jeden $\mathrm{z}$ velkých paradoxů, protože formálně vzato oficiální ideologie meziválečného Československa český národ zrušila zavedla nový československý národ ${ }^{2}$, který byl tvořen dvěma větvemi, českou a slovenskou. Tento paradox byl v mnohém umožněn tehdejší situací na Slovensku, neexistencí slovenského vysokého školství před rokem 1918, nebot’ česká věda - nejen historická - tak mohla být chápána jako československá ${ }^{3}$, třebaže se to dařilo prosazovat víceméně jen díky Čechům působícím na nově založené Komenského univerzitě v Bratislavě, zatímco mladí Slováci postupně směřovali k národní emancipaci, k zdůrazňování rozdílů mezi Čechy a Slováky, k požadavkům slovenské autonomie ${ }^{4}$.

Zatímco meziválečná éra zdůrazňovala především roli zahraničního odboje (Tomáše G. Masaryka, Edvarda Beneše, Milana Rastislava Štefánika, př́ípadně zahraničních legií) a nepř́mo tím oslabovala význam domácího odboje (Maffie a zejména prvního československého premiéra Karla Kramáře $)^{5}$, po druhé světové vál-

1 Československo 1918-1938/2018, eds. P. A. Bílek, B. Jiroušek, L. Novotný, České Budějovice 2018.

2 Z. Kárník, Malé dějiny československé (1867-1939), Praha 2008, s. 30-31.

3 „Obnovení čsl. státní samostatnosti přineslo československé historiografii nové pracovní podmínky a úkoly, a to jak povahy vnitřní, tak i povahy vnější“. Mj. J. Prokeš, Literatura dějepisná, [in:] Československá vlastivěda X. Osvěta, Praha 1931, s. 255.

4 M. Ducháček, Václav Chaloupecký. Hledání československých dějin, Praha 2014; M. Ducháček et al., Václav Chaloupecký a generace roku 1914, Liberec 2018.

${ }^{5}$ M. K. Krofta, Idea československého státu, [in:] K. Krofta, Z dob naši první republiky, Praha 1939, s. 1-48; A. Hlinka, Čo je dr. Karol Kramáŕ pre Československú republiku?, [in:] Dr. Karel 
ce začaly být hledány nové interpretace, které by více zdůraznily československou spolupráci se Sovětským svazem, resp. českou orientaci na Rusko a Sovětský svaz v moderních dějinách, vděčnost Sovětskému svazu nejen za osvobozování za druhé světové války, ale to, že vývoj Československa je dlouhodobě dán právě výsledky ruského působení. Stalinovo budování vnějšího sovětského impéria ${ }^{6}$ se mělo jevit jako přirozený důsledek dlouhodobé vděčnosti blízkých (slovanských) národů Sovětskému svazu, a to vyžadovalo také patřičné ideologické zdůvodnění7.

Po únoru 1948 nový komunistický režim ještě potřeboval nějakou dobu na upevnění své moci, rozejít se plně s meziválečnou tradicí tak mohl až tehdy, kdy už měl moc pevně v rukou ${ }^{8}$. Teprve tehdy mohl odmítat první republiku jako „buržoazní", jež — i snažením Tomáše G. Masaryka — ukradla dělníkům jejich vítězství, jejich osvobození se od Rakouska-Uherska ${ }^{9}$. Prvními z těch, kdo tuto sovětizaci historické vědy prováděli, byli historikové Oldřich Ř́íha a Jaroslav Charvát, kteří propagovali sovětské pojetí historické vědy, tedy de facto ideologické odůvodňování stranických premis ${ }^{10}$, ostatně byli oni — společně s Václavem Husou — prvními historiky povolanými na Filozofickou fakultu Univerzity Karlovy hned po únoru 1948, Akčními výbory Národní fronty ${ }^{11}$.

Zatímco v meziválečné éře se vznik Československa stal zdrojem inspirace pro řadu básní či dramatických děl ${ }^{12}$, často velmi schematických, po roce 1948

Kramář Život - dílo - práce vůdce národa II, eds. V. Sís, A. Pokorný, Praha 1937, s. 132-140; K. Stloukal, Československý stát v představách T. G. Masaryka za války, Praha 1930. K dnešnímu studiu československého zahraničního odboje zvl. D. Vácha, Bratrstvo. Všední a dramatické dny československých legií v Rusku (1914-1918), Praha 2015; idem, Ostrovy v bouři. Každodenní život československých legií v ruské občanské válce (1918-1920), Praha 2016, ke snaze T. G. Masaryka oslabovat vliv Karla Kramáře R. Vašek, ,, Račte to podepsat libovolnou šifrou. “ Prezident Masaryk jako anonymni publicista (1918-1935), Praha 2018, zvl. s. 57-70.

${ }^{6}$ F. Bettanin, Stalin e l'Europa. La formazione dell'imperio esterno sovietico (1941-1953), Roma 2006.

7 B. Jiroušek et al., Proměny diskursu české marxistické historiografie, České Budějovice 2008; V. Sommer, Angažované dějepisectví. Stranická historiografie mezi stalinismem a reformním komunismem (1950-1970), Praha 2011; D. Olšáková, Věda jde k lidu!, Praha 2014, v rámci kontextu východního bloku M. Górny, „Die Wahrheit ist auf unserer Seite“. Nation, Marxismus und Geschichte im Ostblock, přel. P. O. Loew, Köln-Weimer-Wien 2011.

${ }^{8}$ V letech 1945-1948 interpretaci dějin ovlivňovali historici spolupracující s Vědeckým ústavem Ústřední rady odborů, se Socialistickou akademií a podobně, teprve po únoru 1948 mohli ovládnout situaci na Karlově univerzitě v Praze, blíže viz B. Jiroušek, Historik Jaroslav Charvát v systému vědy a moci, Praha 2011, s. 116-135.

9 Postupně tak dochází k odmítání výrazných osobností meziválečného Československa, nejprve pravicových osobností, nakonec i samotného prezidenta Masaryka — např́klad J. Pachta, Josef Pekař - ideolog kontrarevoluce, Praha 1948; idem, Pravda o T. G. Masarykovi, Praha 1953; V. Král, O Masarykově a Benešově kontrarevolučni protisovětské politice, Praha 1953 aj.

10 M. Myška, Z dilla hospodářského historika, Ostrava 2010, s. 104.

11 Dějiny Univerzity Karlovy IV, 1918-1990, eds. F. Kavka, J. Petráň, Praha 1998, s. 266.

12 K tomu zvl. texty M. Bauera a P. Deutschmanna v Československo 1918-1938/2018..., srov. též P. Deutchmann, Allegorien des Politischen. Zeigeschichtliche Implikationen des tschechischen historischen Dramas, 1810-1935, Köln-Weimar-Wien 2017. 
to už velkým tématem uměleckého ztvárnění nebylo, naopak byla třeba význam vzniku Československa - v souladu s představami o socialistickém internacionalismu — odheroizovat, „ukrýt“ do minulosti, kde významné dějinné okamžiky měly být spjaty s revolučními úspěchy dělnictva. Jedním z počátečních větších projevů reinterpretace vzniku Československa - opomineme-li článek ministra Václava Kopeckého v komunistickém časopise „Nová mysl“ z podzimu $1947^{13}$ — byla konference Velká ř́jnová socialistická revoluce a naše svoboda, která se uskutečnila v roce 1950 - péčí Socialistické akademie — při př́ležitosti návštěvy sovětského historika Ivana Ivanoviče Udalcova ${ }^{14}$ v Praze, přičemž s referáty vystoupili vedle dalších také Oldřich Říha a Jaroslav Charvát. Už tady je zřejmá snaha přenést důraz vzniku Československa na jiné datum, než byl do té doby zdůrazňovaný 28. ř́jen, když nejenom z referátu Jaroslava Charváta vyplynulo, že vznik Československa byl ovlivněn především ruskou revolucí roku 1917 a dekretem o míru (Brest-litevským mírem), přičemž k vyhlášení nezávislosti Československa reálně došlo 14. ř́ijna 1918 (Socialistickou radou, odbory), zatímco 28. ř́jen je už jen potvrzením daného stavu, fakticky ukradením republiky lidovým vrstvám ${ }^{15}$. Jaroslav Charvát se $\mathrm{v}$ př́ístích letech věnoval spíše obecným dějinám, zejména však středoškolským učebnicím, zatímco pro Oldřicha Říhu se i nadále hlavním tématem stanou československé dějiny přelomu 19. a 20. století, samozřejmě plně v souladu s leninskou (stalinskou) ideologií, jakkoli se bude snažit zdůrazňovat hospodářské aspekty dějin, tedy on bude hlavním garantem výkladu vzniku Československa pro další desetiletí. Pro další interpretační vývoj vzniku Československa byla podstatná brožura Jurije Křížka a Oldřicha Říhy Bez Velké rŕjinové socialistické revoluce by nebylo Československa ${ }^{16}$ z roku 1951, nicméně výrazněji do interpretace vlivu ruských dějin na vznik Československa zasáhly až roky 1955 a 1957, tedy výročí ruských revolucí z let 1905 a 1917, nebot' ruská revoluce 1905, její padesáté výročí, bylo důvodem připomenout ,první velikou lidovou revoluci epochy imperialismu“ také v Československu ${ }^{17}$. Od ruské revoluce 1905 bylo údajně možné vidět „přímou vývojovou linii“ $\mathrm{k}$ říjnové revoluci 1917, a tedy i ke vzniku Československa, čemuž byla věnována v říjnu

13 V. Kopecký, Nové Československo zdraví 30 vitězných let Sovětského svazu, „Nová mysl“ 1, 1947, č. 4, s. 2-8. Kopeckého článek se tématu dotýká spíše okrajově, ale z hlediska interpretace nového konstruování paměti socialistické společnosti stojí zřejmě na počátku této reinterpretace k problému obecně viz A. Assmannová, Prostory vzpomínání. Podoby a proměny kulturni paměti, přel. J. Flanderka, S. Ondroušková, J. Soukup, Praha 2018, s. 147-150.

14 K I. I. Udalcovovi a jeho pozdějšímu negativnímu vlivu na československou historickou vědu V. Prečan, V kradeném čase, Praha-Brno 1994, s. 284.

15 J. Charvát, Vliv Velké ř́jinové revoluce na dělnické hnutí v českých zemich, [in:] Velká ř́ijnová socialistická revoluce a naše národni svoboda, Praha 1950, s. 41-50.

16 J. Křǐžek, O. Říha, Bez Velké ř́jnové socialistické revoluce by nebylo Československa. Boj české a slovenské dělnické třidy za svobodu v letech 1917-1920, Praha 1951. Další texty, včetně slovenských autorů (mj. Miloš Gosiorovský), přinášel v přŕštích letech také časopis „Sovětská věda — Historie“, resp. jeho nástupce „Sovětská historie“.

17 Úvodem k pátému ročníku „,Sovětské historie“, „Sovětská historie“ 5, 1955, č. 1, s. 1-2. 
1955 velká celostátní konference ${ }^{18}$, která v dobovém duchu zdůrazňovala ohlasy daných revolucí mimo vlastní Rusko ${ }^{19}$, tedy vzhledem $\mathrm{k}$ místu konání především v jednotlivých regionech budoucího Československa.

Skutečné kanonizování tohoto tématu však přinesl až rok 1957, čtyřicáté výročí událostí roku 1917. Vedle dílčích článků na dané téma ${ }^{20}$ vyšla především Ř́ihova velká monografie Ohlas ř́ijnové revoluce v ČSR ${ }^{21}$, která až do roku 1989 vytvořila základní rámec výkladu vzniku Československa, představovala text, bez něhož nebylo možné počátky československé státnosti v rámci hegemonistické marxisticko-leninské ideologie kontextualizovat, tedy ani vykládat širší souvislosti vzniku Československa bez zmínek o přímé př́ičinné souvislosti s ruskou revolucí $1917^{22}$.

Marxisticko-leninská ideologie, vycházející z myšlení 19. století, se staví k výkladu minulosti z pozice omnipotentního vypravěče, má (mnohdy jen zdánlivě, ze svého ideologického východiska) pod kontrolou prostor a čas svého př́iběhu ${ }^{23}$, což se samozřejmě přenáší i do výkladu nejnovějších dějin, kde faktografičnost je nahrazována revoluční rétorikou, fakta jsou použivána především jako exempla, př́íklady, ale zařazení do kánonu je dáno celkovým ideologickým souzněním ${ }^{24}$ s povolenými řečovými akty, kde na texty v pravém slova smyslu nelze vztahovat pravdivostní kritéria, spíše je tu na zvážení otázka vztahu „fikčnosti a faktuálnosti “ ${ }^{\text {‘ }}$, kdy můžeme souhlasit se sociologem práva Jiřím Přibáněm, že „,věda je možná pouze tehdy, pokud její vnitřní kritéria pravdivosti a omylu nejsou odvozena od

18 Celostátni konference $k$ výroči první ruské revoluce v letech 1905-1907, „Sovětská historie“ 5,1955 , č. 6 , s. 671 — za úvodníkem následují jednotlivé texty referátů z dané konference — podrobněji viz B. Jiroušek, Časopis , Sovětská věda - Historie“ “jako „,vzor “ historikovy práce a nástroj ideologizace vědy, „Soudobé dějiny“ 20, 2013, s. 379-398, zde s. 396.

19 Studium ohlasů různých revolučních událostí v dějinách v dalších zemích socialistického tábora (od husitství po 20. století) bylo domluveno sovětskou historičkou Annou Michajlovnou Pankratovou s delegacemi historiků z východního bloku na sjezdu mad'arských historiků v Budapešti v roce 1953. Viz B. Jiroušek, Sjezd mad’arských historiku 1953 - počátek spolupráce historiku Východního bloku, [in:] Naše měna je pevná, Praha-Plzeň 2013, s. 120-125, opominout také nelze, že A. M. Pankratova se věnovala právě ruské revoluci z let 1905-1907, vedle toho psala také středoškolské učebnice (některé z nich byly v padesátých letech také přeloženy do češtiny) — viz R. E. Zelnik, Perils of Pankratova. Some Stories from the Annals of Soviet Historiography, Seattle-London 2005.

20 Ústav dějin a Archiv Univerzity Karlovy Praha, fond Oldřich Říha, karton 11 (neuspořádáno), žádosti novin o zpracování článků na dané téma z léta 1957, mj. pro „Učitelské noviny“; jsou zde dochovány i rukopisy a strojopisy daných článků.

21 O. Říha, Ohlas ř́jnové revoluce v ČSR, Praha 1957.

22 Srov. J. Galandauer, Vznik Československé republiky 1918. Programy, projekty, predpoklady, Praha 1988, mj. s. 217-226. Vzhledem k tomu, že značnou část této knihy tvoří edice dokumentů z doby první světové války, programy politických proudů v domácím i zahraničním odboji, lze knihu chápat jako ediční zpř́ístupnění pramenů, proto v mnoha ohledech mohla tradiční rétorika ustoupit do pozadí, nicméně nemohla být zcela vynechána.

23 V. Papoušek, P. A. Bílek, Cosmogonia. Alegorické reprezentace „, všeho“, Praha 2011, s. 76.

24 Ibidem, s. 92.

25 D. Skalický, Ozvláštněni - fikce - estetická zkušenost, České Budějovice 2017, s. 54. 
nějaké oficiální, politicky vynutitelné ideologie“ ${ }^{26}$. V tomto směru nelze pochybovat o tom, že výklad o vlivu ruské revoluce 1917 na vznik Československa nebylo do roku 1989 možné (oficiálně, veřejně) falsifikovat, jen dokládat větším či menším množstvím přikladů, tedy vlastně v oblasti vzniku Československa šlo spíše o vytváření fikčních světů než o skutečnou realitu ${ }^{27}$, šlo o mýty revoluční kultury ${ }^{28}$, které měly být základem fungování Československa, ale zároveň vlastně celého východního bloku, součástí ideologického boje mezi Východem a Západem ${ }^{29}$.

$\mathrm{V}$ tomto kontextu musíme nahlížet také na knihu Ohlas ř́jnové revoluce $v$ ČSR Oldřicha Říhy, která chtěla ukazovat „rozhodující význam Velké říjnové socialistické revoluce $\mathrm{v}$ boji našich národů za svobodu národní a za svržení utlačovatelského systému bývalé monarchie i první fázi nerovného boje s novým utlačovatelem — vlastní buržoasii “ ${ }^{\text {30 }}$. První světová válka je tak pro Oldřicha Říhu komplotem buržoasie, jejích zájmů v celosvětovém měřítku, zatímco jedinou společenskou tř́́dou, která mohla vše rožrešit, se stala dělnická tř́́da ${ }^{31}$. Ani ta však — v zajetí sociálně-demokratických stran — nedokázala najít řešení, nebot' nepochopila „těsnou spojitost mezi tř́dním a národně osvobozeneckým bojem“332, teprve správné revoluční pochopení Marxových myšlenek (Vladimírem Iljičem Leninem) umožnilo najít řešení, $\mathrm{k}$ tomu však byla dlouhá cesta, mimo jiné spojená s hladověním za války. V českém prostředí si tak hladovějící dělníci už po únorové revoluci 1917 uvědomují, že boj ruských dělnických mas ,je částí jejich boje“333, ale sociální demokracie to neuměla správně pojmout, zatímco česká buržoasie se odklání od Ruska (padl carismus) a začíná spoléhat na západní imperialisty (a tedy i Tomáše G. Masaryka) ${ }^{34}$. České dělnictvo však ani po ruské ŕíjnové revoluci stále nemá plně revolučně uvědomělou (komunistickou) stranu, „,ílevědomě směřující k uskutečnění socialistické revoluce, ale jako dělnictvo celého světa i ono svým tř́dním vědomím pochopilo, co znamená a jaký má význam pro dělnické hnutí první socialistická revoluce světa“335.

Oldřich Říha „dokládá“ $z$ drobných zmínek o dění v Rusku ve válečném tisku habsburské monarchie ${ }^{36}$ obrovský zájem českých dělníků o boj ruských (sovětských) dělníků, ohlas ruských událostí, ovšem v poznámkách (konkrétních datech či alespoň dobových proklamacích) mu tyto ohlasy víceméně absentují, s výjimkou

26 J. Přibáň, Na stráži jednoty světa: marxismus a právní teorie, [in:] Komunistické právo $v$ Československu. Kapitoly z dějin bezpráví, eds. M. Bobek, P. Molek, V. Šimíček, Brno 2009, s. 58.

27 A. Haman, Literární dílo a soudobá literární véda, Praha 2012, s. 64-65.

28 Koncept revoluční kultury v českém prostředí použil zejména Jan Randák v souvislosti s revolucí 1848. Srov. idem, Kult mrtvých, Praha 2007.

29 R. Service, Soudruzi. Světové dějiny komunismu, přel. P. Kaas, Praha 2009, s. 239 n.

${ }^{30}$ O. Ǩíha, Ohlas ř́jnové revoluce v ČSR..., s. 10.

31 Ibidem, s. 27.

32 Ibidem, s. 29.

33 Ibidem, s. 57.

34 Ibidem, s. 67.

35 Ibidem, s. 73.

36 Např. ibidem, s. 74. 
listopadu 1917, kdy proběhly v řadě měst habsburské monarchie demonstrace ${ }^{37}$. Vzásadě se dá ŕíci, že všechny hladové bouře počátku roku a jara 1918 Oldřich Říha považuje za projevy ohlasu ruské revoluce, dokonce i česká buržoazie, dovolávající se historického státního práva, si dodává odvahu hlásit se o svou samostatnost jen pod vlivem ř́ijnové revoluce $\mathrm{v}$ Rusku ${ }^{38}$. Nezávislost Československa tak vystávkuje hladový pracující lid ${ }^{39}$, který 14 . října 1918 dosáhl národní svobody ${ }^{40}$, ale sociální demokracie se zalekla svého vítězství, prridala se na stranu buržoasie, která před dělnictvem hledala záchranu u monarchie ${ }^{41}$. Rozklad habsburské monarchie však pokračoval, 28. ř́jjna tak došlo k obnově dělnických manifestací za republiku, které se ovšem buržoazie snažila překrýt hudbou, zdůrazněním míru, konce války, tedy neškodnými oslavami ${ }^{42}$. Po vyhlášení samostatnosti — jednoznačně dané „nekompromisním postojem dělnické tř́dy a její vůle“ — se buržoasie usilovně snaží o ,ztlumení revoluční vlny“43. Zatímco v Čechách, mimo jiné spojenectvím T. G. Masaryka a buržoasie, se revoluční vlna rychle otupila, na Slovensku propukla opožděně, v důsledku vykořistování, o něž usiluje česká i mad'arská buržoasie ${ }^{44}$. Podle Oldřicha Ř́hy však versailleský systém postupně vede $\mathrm{k}$ nové revoluční vlně ${ }^{45}$, $\mathrm{k}$ formování revoluční levice ${ }^{46}$, směřující ke Kominterně ${ }^{47}$ a k založení Komunistické strany Československa ${ }^{48}$.

$\mathrm{Z}$ tohoto paradigmatu se nevymanila česká historiografie ani koncem šedesátých let, jakkoli tu výraznější roli hrálo výročí konce druhé světové války, chápané jako osvobození Československa Sovětským svazem v roce $1945^{49}$. Ale dokonce ani velmi liberální historička Věra Olivová - v knize iniciované Františkem Grausem Naše živá i mrtvá minulost jako revize „,starého “ způsobu výkladu dějin v roce 1968 - se neodvážila nepřipomenout ruskou revoluci roku 1917, jakkoli se př́mé souvislosti mezi vznikem Československa a ruskou revolucí poněkud vyhnula:

Revoluční pohyb, jehož vyvrcholením a zároveň novým impulsem byly ruské události roku 1917, byl spolu s vlastním průběhem války hlavní přičinou vzniku rozsáhlého velmocen-

37 Ibidem, s. 75.

38 Ibidem, s. 81. Ke koncepci historických českých státních práv viz J. Kalousek, České státní právo, Praha 1871, 2. vydání 1893. Srov. B. Jiroušek, Josef Kalousek. Historik v národní společnosti druhé poloviny 19. století, Praha 2018, s. 65-77.

39 O. Ríha, Ohlas ř́jnové revoluce v ČSR..., s. 110-127.

40 Ibidem, s. 127.

41 Ibidem, s. 129.

42 Ibidem, s. 135.

43 Ibidem, citáty s. 139, 141.

44 Ibidem, s. 174-182, mj. v souvislosti s Mad'arskou (a Slovenskou) republikou rad.

45 Ibidem, s. 183.

46 Ibidem, s. 200-225.

47 Ibidem, s. 229.

48 Ibidem, s. 245.

49 B. Jiroušek, Moderni dějiny a časopis „Nová mysl“ v roce 1965, [in:] Předjaří. Československo 1963-1967, eds. J. Petráš, L. Svoboda, Praha-České Budějovice 2016, s. 267-273. 
ského vakua ve střední, východní a jihovýchodní Evropě, z něhož se zrodil i nový československý stát ${ }^{50}$.

Po uvolněné atmosféře z jara 1968 docházelo v Československu k opětovnému utužování ${ }^{51}, \mathrm{k}$ návratu prosovětských kádrů do nejvyšších funkcí ve vědě ${ }^{52}$, což platilo i pro Oldřicha Říhu, který se nově stává — vedle vedení katedry na Karlově univerzitě — také ředitelem Ústavu československých a světových dějin Československé akademie věd, do pozice zástupce ředitele tohoto ústavu se dostává již zmiňovaný Jurij Kř̌žžek, mimo jiné dávný spoluautor Oldřicha Říhy v publikacích týkajících se ruské revoluce 1917. Již toto jejich oficiální postavení v znormalizovaném Československu vede $\mathrm{k}$ paradigmatickému návratu interpretací z éry padesátých let do hlavního proudu výkladu moderních dějin, přitom nemůžeme přehlížet ani to, že nepatřili k publikačně př́liš výkonným historikům, tedy důraz na jejich dávné publikace vytvářel základ moderních dějin, jež jinak mezi historiky př́liš oblíbeny nebyly, nebot' byly nejvíce poplatné ideologii. Vedle nich se jako výrazná osobnost výzkumů meziválečné doby prosazoval také obávaný ideolog Karel Herman, ostatní historici moderních dějin (20. století) se alespoň formálně museli zaštitovat jejich autoritou, také oni - spolu např́klad s Václavem Králem ${ }^{53}$ - rozhodovali o akademických kariérách svých kolegů.

Jurij Kř́žžek tak v sedmdesátých letech vrací interpretaci událostí první světové války, rozpadu Rakousko-Uherska, do souřadnic ideologického boje mezi Východem a Západem, nebot' podle něho tyto události v kapitalistických zemích jsou vykládány antimarxisticky, snaží se oslabovat „vliv marxistické historiografie“" ${ }^{\text {“54, }}$, dokonce si dovolují shledávat důvody, proč Rakousko-Uhersko nemělo zaniknout ${ }^{55}$. Podle Jurije Křřžka tak na Západě neprávem zdůrazňují „osvobozeneckou legendu“, kterou — pod vlivem publicistiky Tomáše G. Masaryka a Edvarda Beneše - můžeme vidět právě v zdůrazňování zahraničního odboje, jeho zásluh na vzniku Československa ${ }^{56}$. V podobném duchu byla vnímána ruská revoluce 1917 i v dalších letech, samozřejmě také v roce 1977 v textech Jana Galandauera, který zdůrazňoval kontinuitu s pracemi Oldřicha Říhy a Jurije Křížka z padesátých let ${ }^{57}$,

50 V. Olivová, Svoboda mezi válkami, [in:] Naše živá i mrtvá minulost, ed. F. Graus, Praha 1968, s. 187.

51 Jaro '68 a nástup normalizace. Československo 1968-1971, eds. J. Petráš, L. Svoboda, České Budějovice- Praha 2017.

52 J. Hanzal, Cesty české historiografie 1945-1989, Praha 1999, mj. s. 171.

53 R. Šperňák, ,Se soudružským pozdravem “ zůstávám dál. Rok 1968 v životě a díle Václava Krále, [in:] Proměny diskursu české marxistické historiografie..., s. 403-411.

54 J. Křǐžek, Nékteré otázky výkladu dějin rozpadu Rakouska-Uherska, [in:] Studie z obecných dějin. Sbornik historických praci k šedesátým narozeninám prof. dr. Oldřicha Řihy, DrSc., Praha 1972, s. 95-111, zde s. 99.

55 Ibidem, s. 101-102.

56 Ibidem, s. 105.

57 Srov. mj. J. Galandauer, Ohlas Velké ř́inové socialistické revoluce v české společnosti, Praha 1977, mj. s. 6-8, 215 (poznámka 1 celé knihy). 
spolu se svými výzkumy Bohumíra Šmerala ${ }^{58}$ nicméně kladl větší důraz na aktivity sociálních demokratů, jimž odporovali ostatní vrstvy české společnosti ${ }^{59}$, což přetrvalo i do dalšího desetiletí — Karel Herman tak v roce 1982 vnímal ruskou revoluci roku 1917 jako ,základní mezník světových dějin, od něhož se odvíjí proces přechodu lidstva z kapitalismu do socialismu“, který však je „předmětem zlobných útoků ideologů a apologetů kapitalismu“600. Normalizační Československo tak nebylo schopno výrazněji pokročit v konceptualizaci vzniku Československa — jako důsledku ruské revoluce 1917 — nad teze doznívajícího stalinismu padesátých let, zvláště nad tehdejší texty Oldřicha Říhy, bylo pouze schopno kritizovat buržoasní názory na dané dějinné události. Blížilo se však sedmdesáté výročí roku 1917, které bylo třeba připomínat i v přestavbové éře ${ }^{61}$, samozřejmě včetně zásluh říjnové revoluce o vznik Československa:

Při př́ležitosti 70. výročí Velké říjnové socialistické revoluce zdůrazňujeme historický význam Velkého října v rozvoji zápasů našeho lidu za národní a sociální osvobození, za vybudování socialismu a pevného mezinárodního postavení Československa.

Již zrod novodobé československé státnosti je spojen s inspirujícím př́íladem, který k nám přicházel ze země Řijnové revoluce. Leninské zásady sebeurčení národů výrazně aktivizovaly v průběhu roku 1918 dlouholetý národně osvobozenecký zápas Čechů a Slováků za vytvoření samostatného státu a přispěly $\mathrm{k}$ jejich národní nezávislosti, ke vzniku Československé republiky ${ }^{62}$.

Časopis Ústředního výboru KSČ „Nová mysl“ uspořádal v roce 1987 konferenci na dané téma a postupně otiskl řadu písemných verzí referátů, na úvod tak mimo jiné přinesl text historika Jana Galandauera Ohlas Velké ř́jjnové socialistické revoluce a národně osvobozenecký boj českého a slovenského národa ${ }^{63}$, který ukazoval, že v ideologicky (marxisticko-leninsky) pojatém prostředí vlastně nelze v takto stěžejních otázkách moderních dějin výraznější změny názorů očekávat, jakkoli se v poznámkovém aparátu jeho studie objeví mimo jiné odkazy na texty Edvarda Beneše, ale v nepodstatných faktografických záležitostech, nikoli v interpretační rovině, přece jenom je však vidět oproti padesátým letům posun v tom, že už je jako základní datum vzniku Československa vnímán 28. říjen 1918, jakkoli výše stále cení předcházející sociálně demokratické aktivity ze 14.-15. ř́jna ${ }^{64}$.

58 Bohumír Šmeral — sociální demokrat, v roce 1921 zakladatel Komunistické strany Československa.

59 J. Galandauer, Ohlas Velké říjnové socialistické revoluce..., mj. s. 81-82; srov. též J. Galandauer, Bohumir Šmeral, Praha 1978 (a další vydání).

${ }^{60} \mathrm{~K}$. Herman, Velká ř́inová socialistická revoluce a teorie ,,industriální společnosti“, [in:] Historiografie čelem k budoucnosti. Sborník k šedesátinám akademika Jaroslava Purše, Praha 1982, s. 121-140, zde s. 121.

${ }^{61}$ Rok 70. výroči Velkého ř́jna, „Nová mysl“" 41, 1987, č. 2, s. 3-11.

${ }^{62}$ Ideové politické pojetí 70 . výroči Velké ř́jinové socialistické revoluce. Z usnesení sekretariátu ÚV KSČ ze dne 17. dubna 1987, „Nová mysl““ 41, 1987, č. 6, s. 77-83, citát s. 79.

63 J. Galandauer, Ohlas Velké rínnové socialistické revoluce a národně osvobozenecký boj českého a slovenského národa, „Nová mysl“ 41, 1987, č. 7-8, s. 139-150.

${ }^{64}$ Ibidem, s. 149-150. 
Pokud se z tohoto zajetí ideologie nedokázal plně vymanit ani Jan Galandauer, nešlo to v žádném případě očekávat ani od dalších „vưdčích“ osobností „,výzkumu“ moderních dějin v Československu, Zdeňka Snítila, Jurije Křǐžka či Vladimíry Grycové a dalších ${ }^{65}$, včetně výrazných osobností dobové politiky, mimo jiné tajemníka ÚV KSČ Jana Fojtíka, a dalších představitelů komunistických stran, nejen z Československa ${ }^{66}$.

Jakkoli by bylo možno zmínit i další marxisticko-leninské texty, které se ke vzniku Československa — ve vazbě na ř́ijen 1917 — vyjadřují, základní kontexty tohoto vnímání byly představeny, závěrem tak můžeme shrnout, že prakticky za celé období let 1948-1989 nedošlo k interpretační změně pohledu na vznik Československa. Třebaže v šedesátých letech se ozývalo volání po zavedení státního svátku na 28. ř́jen jako den vzniku Československa, jenž byl zrušen už v roce 1951 (chápán jako den znárodnění v odkaze na prezidentské dekrety Edvarda Beneše $\mathrm{v}$ roce 1945$)^{67}$, $\mathrm{k}$ jeho obnově nakonec došlo na samém sklonku existence socialistického Československa — v roce $1988^{68}$, kdy už také méně vadily zmínky o T. G. Masarykovi, jakkoli bylo upozorňováno na jeho nedostatečnou pokrokovost — uvítal pád carského režimu v Rusku (únorovou revoluci), ale už neocenil revoluci říjnovou, nicméně se nakonec nezapojil (s československými legiemi) do př́mého boje s bolševiky ${ }^{69}$.

Osmičkové roky v českých a československých dějinách se vyskytují poměrně často, v roce 1988 tak nemělo být př́iliš připomínáno sedmdesáté výročí vzniku Československa, nebot' nejdůležitějším výročím mělo být čtyřicáté výročí února 1948, které mělo překrýt vše ostatní (včetně mnichovských událostí v září 1938 či polednového vývoje v roce 1968), ale připomenutí vzniku Československa — samozřejmě jako důsledku úsilí proletariátu, kterého sociální demokracie neuměla

65 Z. Snítil, Vliv idejí Velkého řínna, „Nová mysl“ 41, 1987, č. 9. s. 13-24 (Zdeněk Snítil se otištění tohoto textu, úvodního referátu konference uspořádané ÚV KSČ v květnu 1987, už nedožil); J. Kř́žžek, V. Grycová, Proletářská revoluce v Rusku a česká inteligence (1917-1921), „Nová mysl“ 41, 1987, č. 9, s. 25-36; V. Čada, Velká řijnová socialistická revoluce a založení KSČ, „Nová mysl““41, 1987, č. 10, s. 61-72; J. Heřtová, Odkaz Řijna a socialistická kultura, „Nová mysl“ 41, 1987, č. 10, s. 73-83.

${ }^{66} \mathrm{Mj}$. J. Fojtík, Cestou Velkého ř́jna $\mathrm{k}$ dalšímu rozvoji socialismu, za štastnou budoucnost v míru, „Nová mysl“" 41, 1987, č. 11, s. 4-12.

67 J. Rauchová, ,,V zájmu povznesení národniho a státního vědomí Čechů a Slováků se doporučuje, aby dny 28. a 30. ř́jna byly vyhlášeny za dny zrodu Československé republiky. “IV. sjezd československých historiků a rezoluce o obnoveni označeni 28. řijna jako dne vzniku Československé republiky, [in:] Československo 1918-1938/2018..., s. 273-283.

68 Ibidem, s. 283.

69 J. Galandauer, T. G. Masaryk a vznik ČSR, Praha 1988, s. 23 (tuto drobnou — čtyřicetistránkovou - brožuru vydalo nakladatelství Československé strany socialistické Melantrich, jež přece jenom situaci vidělo poněkud odlišně od hlavních nakladatelství, více kontrolovaných komunistickou stranou). 
využít ${ }^{70}$ - bylo vnímáno jako mnohem méně problematické než obavy z konotací roku $1968^{71}$.

Marxisticko-leninský výklad vzniku Československa se tak ustaluje velmi brzy po roce 1948, v raných padesátých letech, mimo jiné zásluhou Oldřicha Říhy, přičemž tato revoluční interpretace zůstává neměnná až do konce režimu, v souladu s konceptem revoluční kultury, kdy po nastavení rituálů oslav a dobojování prvních bojů už nemá být společnost znejišt’ována proměnami interpretací minulosti ${ }^{72}$, což nastává okrajově koncem šedesátých let (zejména s odkrýváním politických procesů padesátých let, mimo jiné v textech Karla Kaplana) ${ }^{73}$, ale brzy dochází $\mathrm{k}$ návratu $\mathrm{k}$ tradicím nastaveným $\mathrm{v}$ padesátých letech. Vedlo to samozřejmě v oblasti moderních dějin $\mathrm{k}$ vnitřnímu vyčerpání — i ve vztahu $\mathrm{k}$ interpretacím vzniku Československa, kdy od padesátých let nebylo možné k vzniku Československa víceméně nic nového napsat, tedy z hlediska oficiální historiografie; v samizdatu či v zahraničí se rozvíjely mimo jiné diskuse o T. G. Masarykovi. Jakékoli — i marxisticko-leninské — bádání by ukazovalo, že živelné hladové bouře podzimu 1917 a jara $1918^{74}$ lze spojovat s revolučním bojem v Rusku jen okrajově, což by celou konstrukci odmítající „buržoasni““ odboj (domácí stejně jako zahraniční) za války zcela rozložilo. Pamět' moderních dějin tak byla v socialistickém Československu amnézována a nahrazena stalinským konstruktem, který přežil éru stalinismu skoro o čtyřicet let.

\section{Bibliografie}

Assmannová A., Prostory vzpomínání. Podoby a proměny kulturní paměti, přel. J. Flanderka, S. Ondroušková, J. Soukup, Karolinum, Praha 2018.

Bettanin F., Stalin e l'Europa. La formazione dell'imperio esterno sovietico (1941-1953), Carocci, Roma 2006.

Celostátni konference k výroči první ruské revoluce v letech 1905-1907, „Sovětská historie“ 5, 1955, č. 6.

Čada V., Velká ř́innová socialistická revoluce a založení KSČ, „Nová mysl““ 41, 1987, č. 10.

Československá vlastivěda X. Osvěta, Sfinx, Praha 1931.

Československo 1918-1938/2018, eds. P. A. Bílek, B. Jiroušek, L. Novotný, Jihočeská univerzita, České Budějovice 2018.

Deutchmann P., Allegorien des Politischen. Zeigeschichtliche Implikationen des tschechischen historischen Dramas, 1810-1935, Köln-Weimar-Wien 2017.

70 Ideově politické pojeti významných výročí roku 1988 schválené předsednictvem ÚV KSČ dne 21. ríjna 1987, „Nová mysl“ 42, 1988, č. 1, s. 121-129, zde s. 122.

71 K normalizační společnosti v Československu mj. M. Vaněk, P. Mücke, Velvet Revolutions. An Oral History of Czech Society, New York 2016.

72 M. Zavacká, K problematike výskumu totalitnej komunistickej propagandy: vybrané pojmy, mechanizmy, obsahy, „Historický časopis“ 50, 2002, s. 439-456.

73 B. Jiroušek, „Na přelomu“ aneb „,Jak dál v práci strany“ podle časopisu „,Nová mysl“, [in:] Jaro '68 a nástup normalizace..., s. 368-377.

74 První světová válka a vztahy mezi Čechy, Slováky a Němci, eds. H. Mommsen et al., Brno 2000.

Slavica Wratislaviensia 173, 2020

(C) for this edition by CNS 
Dějiny Univerzity Karlovy IV, 1918-1990, eds. F. Kavka, J. Petráň, Karolinum, Praha 1998.

Dr. Karel Kramár. Život - Dílo - Práce vůdce národa II, eds. V. Sís, A. Pokorný, Praha 1937.

Ducháček M., Václav Chaloupecký. Hledání československých dějin, Karolinum, Praha 2014.

Ducháček M., Bílková J. et al., Václav Chaloupecký a generace roku 1914, Technická univerzita, Liberec 2018.

Fojtík J., Cestou Velkého ř́jna $k$ dalšimu rozvoji socialismu, za štastnou budoucnost v míru, „Nová mysl“" 41, 1987, č. 11.

Galandauer J., Bohumir Šmeral, Horizont, Praha 1978.

Galandauer J., Ohlas Velké ř́jnové socialistické revoluce a národně osvobozenecký boj českého a slovenského národa, „Nová mysl“ 41, 1987, č. 7-8.

Galandauer J., T. G. Masaryk a vznik ČSR, Melantrich, Praha 1988.

Galandauer J., Vznik Československé republiky 1918. Programy, projekty, předpoklady, Svoboda, Praha 1988.

Górny M., „Die Wahrheit ist auf unserer Seite“. Nation, Marxismus und Geschichte im Ostblock, přel. P. O. Loew, Böhlau, Köln-Weimer-Wien 2011.

Haman A., Literární dílo a soudobá literární véda, Arsci, Praha 2012.

Hanzal J., Cesty české historiografie 1945-1989, Karolinum, Praha 1999.

Herman K., Velká ř́jnová socialistická revoluce a teorie „,industriální společnosti“, [in:] Historiografie čelem k budoucnosti. Sbornik k šedesátinám akademika Jaroslava Purše, Ústav československých a světových dějin ČSAV, Praha 1982.

Heřtová J., Odkaz Října a socialistická kultura, „Nová mysl“ 41, 1987, č. 10.

Ideově politické pojetí 70. výroči Velké řijnové socialistické revoluce. Z usneseni sekretariátu ÚV KSČ ze dne 17. dubna 1987, „Nová mysl“ 41, 1987, č. 6.

Ideově politické pojetí významných výročí roku 1988 schválené predsednictvem ÚV KSČ dne 21. ř́ijna 1987, „Nová mysl“" 42, 1988, č. 1.

Jaro '68 a nástup normalizace. Československo 1968-1971, eds. J. Petráš, L. Svoboda, Jihočeské muzeum - Ústav pro studium totalitních režimů, České Budějovice-Praha 2017.

Jiroušek B., Časopis ,, Sovětská věda - Historie“ “jako „,vzor “ historikovy práce a nástroj ideologizace vědy, „Soudobé dějiny“ 20, 2013.

Jiroušek B., Historik Jaroslav Charvát v systému vědy a moci, Arsci, Praha 2011.

Jiroušek B., Josef Kalousek. Historik v národní společnosti druhé poloviny 19. století, Arsci, Praha 2018.

Jiroušek B. Proměny diskursu české marxistické historiografie, Jihočeská univerzita, České Budějovice 2008.

Jiroušek B., Sjezd mad’arských historiku 1953 - počátek spolupráce historiků Východního bloku, [in:] Naše měna je pevná, viaCentrum, Praha-Plzeň 2013.

Kalousek J., České státní právo, J. S. Skrejšovský, Praha 1871, 2. vydání 1893.

Kárník Z., Malé dějiny československé (1867-1939), Dokořán, Praha 2008.

Komunistické právo v Československu. Kapitoly z dějin bezpráví, eds. M. Bobek, P. Molek, V. Šimíček, Masarykova univerzita, Brno 2009.

Kopecký V., Nové Československo zdravi 30 vitězných let Sovětského svazu, „Nová mysl““1, 1947, č. 4.

Král V., O Masarykově a Benešově kontrarevolučni protisovětské politice, SNPL, Praha 1953.

Krofta K., Z dob naši první republiky, Jan Laichter, Praha 1939.

Křížek J., Některé otázky výkladu dějin rozpadu Rakouska-Uherska, [in:] Studie z obecných dějin. Sbornik historických praci k šedesátým narozeninám prof. dr. Oldřicha Říhy, DrSc., Univerzita Karlova, Praha 1972.

Křŕžek J., Grycová V., Proletářská revoluce v Rusku a česká inteligence (1917-1921), „Nová mysl“ 41, 1987, č. 9.

Křrižek J., Říha O., Bez Velké ríjnové socialistické revoluce by nebylo Československa. Boj české a slovenské dèlnické tř́idy za svobodu v letech 1917-1920, Rovnost, Praha 1951.

Slavica Wratislaviensia 173, 2020

(C) for this edition by CNS 
Myška M., Z díla hospodářského historika, Ostravská univerzita, Ostrava 2010.

Naše živá i mrtvá minulost, ed. F. Graus, Praha 1968.

Olšáková D., Věda jde k lidu!, Academia, Praha 2014.

Pachta J., Josef Pekař — ideolog kontrarevoluce, Socialistická akademie, Praha 1948.

Pachta J., Pravda o T. G. Masarykovi, Orbis, Praha 1953.

Papoušek V., Bílek P. A., Cosmogonia. Alegorické reprezentace „, všeho “, Akropolis, Praha 2011.

Prečan V., V kradeném čase, Doplněk, Praha-Brno 1994.

Prvni světová válka a vztahy mezi Čechy, Slováky a Němci, eds. H. Mommsen, D. Kováč, J. Malíŕ, M. Marková, Matice Moravská, Brno 2000.

Předjaři. Československo 1963-1967, eds. J. Petráš, L. Svoboda, Ústav pro studium totalitních režimů - Jihočeské muzeum, Praha-České Budějovice 2016.

Randák J., Kult mrtvých, Argo, Praha 2007.

Rok 70. výroči Velkého ř́jina, „Nová mysl“ 41, 1987, č. 2.

Ríha O., Ohlas ř́jnové revoluce v ČSR, SNPL, Praha 1957.

Service R., Soudruzi. Světové dějiny komunismu, přel. P. Kaas, Argo — Academia, Praha 2009.

Skalický D., Ozvláštnění - fikce — estetická zkušenost, Halama, České Budějovice 2017.

Snítil Z., Vliv idejí Velkého ř́jna, „Nová mysl“" 41, 1987, č. 9.

Sommer V., Angažované dějepisectví. Stranická historiografie mezi stalinismem a reformním komunismem (1950-1970), Nakladatelství Lidové noviny, Praha 2011.

Stloukal K., Československý stát v představách T. G. Masaryka za války, Politický klub Československé Národní Demokracie, Praha 1930.

Ústav dějin a Archiv Univerzity Karlovy Praha, fond Oldřich Říha, karton 11 (neuspořádáno), žádosti novin o zpracování článků na téma VŘSR z léta 1957.

Úvodem k pátému ročníku ,,Sovětské historie“, „Sovětská historie“ 5, 1955, č. 1.

Vácha D., Bratrstvo. V̌̌edni a dramatické dny československých legii v Rusku (1914-1918), Epocha, Praha 2015.

Vácha D., Ostrovy v bouři. Každodenni život československých legií v ruské občanské válce (19181920), Epocha, Praha 2016.

Vaněk M., Mücke P., Velvet Revolutions. An Oral history of Czech Society, Oxford University Press, New York 2016.

Vašek R., „Račte to podepsat libovolnou šifrou“. Prezident Masaryk jako anonymni publicista (1918-1935), Academia, Praha 2018.

Velká řínová socialistická revoluce a naše národni svoboda, Rovnost, Praha 1950.

Zavacká M., K problematike výskumu totalitnej komunistickej propagandy: vybrané pojmy, mechanizmy, obsahy, „Historický časopis“ 50, 2002.

Zelnik R. E., Perils of Pankratova. Some Stories from the Annals of Soviet Historiography, University of Washington Press, Seattle-London 2005.

\section{Changes of Interpretation on the Establishment of Czechoslovakia in Czech Marxist-Leninist Thought}

\section{Summary}

The text deals with Czech Marxist-Leninist thinking in relation to the establishment of Czechoslovakia in 1918. While in the interwar Czechoslovak culture the formation of Czechoslovakia was heroized, depicted in literary works (poems, dramas, etc.), after 1948 it was rather concealed. Marxist-Leninist historians Oldřich Říha, Jaroslav Charvát and others (on the contrary) explained that the emergence of Czechoslovakia was a consequence of the Russian October Revo- 
lution of 1917, and thus the emergence itself was in its own way irrelevant. According to them, the establishment of a new state was stealing the bourgeoisie's victory for the working class (replacing socialist ideas with nationalism). According to this interpretation Czechoslovakia in the year 1945 (liberation by the Soviet Army) and the year 1948 (Czechoslovak coup d'état) was finally following the "right" historical path opened by the Russian Revolution of 1917.

Keywords: Marxism-Leninism, Czechoslovakia, Czech culture, Czech historiography, World War I

\section{Zmiany w interpretacji utworzenia Czechosłowacji w czeskiej refleksji marksistowsko-leninowskiej}

\section{Streszczenie}

Tekst traktuje o czeskiej refleksji marksistowsko-leninowskiej dotyczącej utworzenia Czechosłowacji w 1918 roku. Podczas gdy w czechosłowackiej kulturze okresu międzywojennego powstanie Czechosłowacji interpretowano w dziełach literackich (poezja, dramat itp.) w kategoriach bohaterstwa, po roku 1948 fakt ten raczej pomijano milczeniem. Historycy marksistowsko-leninowscy (Oldřich Ríha, Jaroslav Charvát i inni) traktowali utworzenie Czechosłowacji jako rezultat rewolucji październikowej 1917 roku, dlatego też samo powstanie państwa było dla nich poniekąd nieistotne. Według nich w trakcie tworzenia nowego państwa burżuazja zawłaszczyła zwycięstwo klasy robotniczej (zamieniając idee socjalistyczne na nacjonalizm). Zgodnie z tą interpretacją Czechosłowacja w latach 1945 (wyzwolenie przez Armię Czerwoną) i 1948 (Praski zamach stanu) wkroczyła w końcu na „właściwą” drogę dziejową, zapoczątkowaną w 1917 roku przez rewolucje w Rosji.

Słowa kluczowe: marksizm-leninizm, Czechosłowacja, kultura czeska, historiografia czeska, I wojna światowa 